\title{
Online Benlik Sunumu ve Narsisizm Arasındaki İlişki: Üniversite Öğrencileri Üzerinde Bir Araştırma
}

\author{
Veysel ÇAKMAK, Yrd. Doç. Dr., Aksaray Üniversitesi, İletişim Fakültesi, \\ veyselcakmak@aksaray.edu.tr,https://orcid.org/0000-0001-5785-7636.
}

ÖZ

\begin{abstract}
İnsanlarda benlik sunumu geçmişten günümüze kadar her zaman var olmuştur. Onlar günlük yaşantısının neredeyse bütün hallerini sunmaktadırlar. "Dünya bir sahne herkes bu sahnede oyuncu" ise teknolojinin geliştiği günümüzde sanal ortamlarda ayn tiyatro oynanmaktadır. Sanal ortamlarda özellikle sosyal medya ortamlarnda insanlar kendi benliklerini resim, video ve metinler yoluyla oluşturmaya çalışmaktadır. Hatta bu ortamlarda insanlar diğer insanların beğenilerine göre hareket etmektedir. Bu da kişinin narsisizme doğru yönelmesine sebep olmaktadır. Bu çalışmada sanal ortamlarda benlik sunumu ve narsisizm arasındaki ilişkisi araştırılmaktadır. Sanal ortam olarak Facebook ele alınmıştır. Çalışma Aksaray Üniversitesi'ndeki öğrencilerden veriler toplanarak yapılmıştır. Elde edilen veriler bilgisayar temelli istatistiki analiz programlarında analiz edilmiştir. Yapılan analiz sonucunda online benlik sunumu ile narsisizm arasında ilişki olduğu tespit edilmiştir. Ayrıca öğrencilerin çoğu interneti dört saat ve daha fazla süreli kullandıklarn ama Facebook' $u$ genellikle bir saatten daha az süreli kullandıkları tespit edilmiştir.
\end{abstract}

Anahtar Kelimeler: Online benlik sunumu, narsisizm, Facebook, sosyal medya, narsistik kişilik.

\section{Relationship Between Online Self-Presentation and Narcissism: A Research on University Student.}

\begin{abstract}
Self-presentation in human beings has always existed from past to present. They present almost all aspects of everyday life. If "the world is a stage and everyone is an actor in this stage", the same theater is played in a virtual environment in our day during which the technology develops. In the virtual environments, especially in social media environments, people are trying to create their own egos through pictures, videos and texts. Even in these environments people are acting according to other people's liking. This causes the individual to be prone to narcissism. In this study, the relationship between self-presentation and narcissism is investigated in the virtual environments. Facebook was used as the virtual environment. This study was performed by collecting data from the students at Aksaray University. The obtained data were analyzed in computer-based statistical analysis programs. As a result of the analysis, it was determined that there is a relationship between online self-presentation and narcissism. In addition, it has been determined that most students use the internet for four hours or more, but they use Facebook for less than one hour
\end{abstract}

Keywords: Online self presentation, narcissism, Facebook, social media, narcissistic personality. 


\section{Giriş}

Benlik kişinin davranış, tutum ve fiziksel kişilik göstergesi olarak bilinmektedir. Her bireyin kendine özgün benlikleri vardır. Bebeklikten itibaren bu özellik oluşmaya devam etmektedir. Kişinin aile çevresi, arkadaş çevresi, okul ve işyeri çevresi bu benliği etkileyen temel faktörlerdir. Bireyler yaşantıları esnasında kendi benliklerini diğer insanların zihinlerinde istedikleri şekilde yer edinmek istemektedirler. Bu durum da benlik sunumuna doğru bizi götürmektedir. Benlik sunumu da kişinin hayatı süresince sürekli olarak kendisini çevreye pozitif gösterme şekli denilebilir.

Günümüzde insanlar teknoloji ile iç içe yaşamaktadırlar. Gerçek hayatlarında benlik sunum davranışlarını aynı şekilde sanal ortama da aktarmaktadır. Özellikle son yıllarda popüler olan sosyal medya araçları bu davranışlar için en çok kullanılan iletişim araçlarıdır. Dolayısıyla insanlardaki benlik sunum ihtiyacı yaşantılarında daima herhangi bir şekilde gerçekleşmektedir.

Narsisizm insanların kendine olan hayranlığıdır. Kelime kökeni olarak Yunan mitolojisinden gelmektedir. Narsistik kişilik ise kişinin kendisini fiziksel ve psikolojik özelliklerini aşırı bir şekilde beğenmesi durumudur. Dijital çağda da insanlar kendisi ile ilgili görüntü ve davranışları abartılı bir şekilde dijital ortama aktardığ 1 düşünülmektedir. Narsisizm açısından bakıldığında insanlar Yunan mitolojisinde olduğu gibi suya bakarak kendini beğenme gibi günümüzde sosyal medya ortamlarında kendine ve çevresine bakarak kendini beğenme durumunu gerçekleştirmektedir.

$\mathrm{Bu}$ çalışmada benlik sunum aracı olarak özellikle gençler tarafından en çok kullanılan sosyal medya iletişim aracı Facebook ele alınmıştır. Online benlik sunum etkinliklerinin son yıllarda fazla olması dolayısıyla online benlik sunumu ve narsisizm konusunun önemli olduğu düşünülmektedir.

\section{Benlik Kavramı Benliğin Gelişimi}

Benlik toplumsal yaşantılar sonucunda kazanılan bir oluşumdur. Çünkü çocuklar ilk yıllarda kendi varlıklarının tam olarak farkında değillerdir. Zamanla toplum içerisinde sosyalleşme sonucu kendini ve çevresini tanımaya başlarlar. Çocuk önce aile çevresini fark etmeye başlar, daha sonra, mahallesini ve okul çevresini tanır ve ona göre davranışlar sergiler (Güney, 2016; 223). Benlik kişinin kendisine ilişkin zihinsel yapısıdır. Toplumsal deneyimden oluşur. Kişi kendisini diğerlerinin tepkilerine göre düzenler ve kendisine ilişkin algılar aracılığıyla yorumlar. (Mutlu, 2012: 45).

Bireyin psikolojik ve sosyal işleyişinde benliğin, belirgin, sınırlı ve ayrık olması veya ilişkili ve akışkan sınırlı olması önemlidir. Su sebeple, benliğin ilişkisel-ayrıklık derecesi temel bir boyut halinde ortaya çıkmaktadır. İlişkisellik psikolojisinde, kültürel, ailesel (grup-kişilerarası) ve bireysel analiz düzeylerinde açık benzerlikler vardır. $\mathrm{Bu}$ 
nedenle, ayrıklık kültürü, kesin sınırlarla belirlenmiş ayrık benlik ilişkilerinin tanımlandığ1 ortamları, yani kültürel, ailesel ve kişilerarası ilişkiler düzenini içerir. Bağlılık kültürü ise sınırları belli olmayan, bağlı, geçişken ve bu yüzden bir ölçüde çakışan benlik ilişkilerinin tanımlandığı ortamları ve ilişki düzenlerini içerir. Bunun haricinde bu iki zıt kutuplarda, farklı ayrıklık-ilişkisellik dereceleri vardır. Yani, ayrıklık-ilişkisellik, çeşitlilik gösteren bir boyuttur (Kağıtçıbaşı, 2010: 146). Benliğe ilişkin bilgilerin çoğu toplumsallaşma yoluyla gelmektedir. Çocukluk sırasında, anne babadan, öğretmenlerden ve arkadaşlardan kişiye karşı belli tarzlarda davranılır. Bu davranış benliği etkiler. Başkalarının kişiye tepki veriş biçimleri olan yansıtılmış benlik algısı da benlik oluşumunda önemli faktördür. Ayrıca kişinin kendini algılama biçimi ve kişinin kendisini çevresi ile karşılaştırarak değerlendirmesi benliğin oluşumuna etki eder. Bununla birlikte kişinin yaşadığı kültürel çevre, ülke, bölge, etnik grup, kültürel değerler, onun benlik oluşumunda önemli olan unsurlardır (Taylor ve ark., 2007: 107-113).

Kişinin yaşadığı kültür ile bireyde varolan benlik arasında ilişki bulunmaktadır. Bu ilişki kişinin kültürünün ayrıklık yada bağlılık durumuna göre değişir. Aşağıdaki tabloda bu durum daha net görülmektedir.

Tablo 1: Analiz Düzeyleri Arasındaki Bağlantılar

\begin{tabular}{|l|l|l|}
\hline $\begin{array}{l}\text { Kültür } \\
\text { Düzeyi }\end{array}$ & $\begin{array}{l}\text { Ayrıklık Kültürü } \\
\text { (ilişkisel Bireycilik }\end{array}$ & $\begin{array}{l}\text { Bağlılık Kültürü } \\
\text { (İlişkisel Bağlılık) }\end{array}$ \\
\hline & & \\
\hline Birey Düzeyi & $\begin{array}{l}\text { Ayrık Benlik } \\
\text { (Bağımsızlık) }\end{array}$ & $\begin{array}{l}\text { İlişkisel Benlik } \\
\text { (Karşılıklı Bağlılık) }\end{array}$ \\
\hline
\end{tabular}

Kaynak: (Kağıtçıbaşı, 2010: 148).

Benlik topluma göre değişen bir olgudur ve kişinin gelişimini etkiler. Örneğin Japonya'da bir anne, iki yaşındaki benmerkezci bir çocukla yüzleşme eğilimi göstermez. Bunun yerine, çocuğuna "tahammül ederek" davranışının kendisine üzüntü ve sıkıntı verdiğini belirtir. Bu şekilde, çocuk daha çok küçük yaştan itibaren davranışlarının diğer insanlar açısından sosyal ve duygusal sonuçları olduğunu anlamaya yönlendirilir. Sebep olduğu sıkıntıdan dolayı sorumluluk ve suçluluk hissetmesi sağlanır; böylece sıkıntıya neden olmamanın ve suçluluk hissetmek zorunda kalmamanın bir yolu olarak kendini kontrol etmeyi öğrenir. Bu mesajlar çocukluk dönemi boyunca devam eder ve yetişkin davranışı üzerinde güçlü etkiler bırakır (Hayes, 2011: 28).

Duygusal ve davranışsal açıdan güçlük çeken tüm çocukların temel özelliklerine bakıldığında düşük benlik saygılarının olduğu görülmektedir. Onların kırılgan benlik değerlerini korumak için başetme stratejilerini anlamaya dönük çalışmalar yapılabilir. 
Benlik saygısı ve okula uyum sağlama, çocuk bakımıyla ilgili kişi ile çocuk arasındaki yaşlardaki ilişkinin kalitesiyle belirlenmektedir. Yüksek benlik saygısına sahip çocuklar ise sınıf içi davranış özelliklerinden bakıldı̆̆ında, sınıf içi etkinliklere güvenli bir şekilde yaklaşmaları ve daha yaratıcı olmaları, bağımsız ve başarılı olmaları görülmüştür. Okuldaki başarısızlık, onların güçsüz benlik değeri algılarına eklenecek ve hızla gerilemelerini saglayacaktır (Uşaklı, 2013: 262).

Bebeğin yer yüzüne inişinin donanımlı bir başlangıç olduğunu kabul etmek zorundayız. Onun belli bir örgütlenme içinde yeryüzünde karşılaşacaklarını az çok bilir bir halde doğduğu söylenebilir. Onun bir yüz tarafından karşılanacağı, doğduğunda tutunma, yada sarılma gibi reflekslerinin var olduğu bilinmektedir. İnsan, boş bir masanın üzerine nesnelerin çizdiği bir resim değildir, aksine onun içinde yer yüzünün siyah beyaz bir resmi vardır ve karşılaştığı nesnelere göre bu resmin bazı bölümleri boyanır, renk alır. Bazı bölümleri ise renksiz kalır. O halde bebeğin içindeki resmi çizen nedir? Bunun cevabı benliktir. Ortak benlik insan türünün geçmişinde yaşamış milyarlarca üyesinin yeryüzüne ilişkin aktardıkları ile derinliğine ve genişliğine bir bilgi sahibidir. Bebek yeryüzüne gelirken bu bilginin tamamını içine alır. Bu sebeple nesneler dünyasına indiğimizde boyadığımız resim, içimizdeki büyük resmin yanında küçük bir parçadır. Bir nesne ile bir yüz arasındaki fark ise birinin ardında birlerce yıllık tarih, diğerinin ardında ise bu tarihin bulunmamasıdır. Yüz nesneden farklı olarak insanın kendisidir. Bebek kaşısındaki yüze yöneldiği zaman aslında kendine yönelmiş olur, kendi içinden kendi resmini çıkarmayı hedef alır. Çünkü ortak benlik kendinin parçalarını hazır olarak vermiştir, bebek sahip olduğu kendinin bilgisine yönelir (Ceylan ve diğerleri, 2015).

Benliğin kültürel ortamda yapılandırılması, kişinin sosyalleşme süreci üzerinde doğrudan etkilidir. Bunun nedeni çocuk yetiştirme ve sosyalleşme amacına yönelik olmasıdır. Bu amaç, kültürel açıdan değer verilen davranışların yetişen insanda oluşması ve etkin benliğin geliştirilmesidir. Çoğunlukla kültürel değerler ve çocuk yetiştirme düzenleri arasındaki bağı görmek gerekir. Örneğin Amerika' da değer verilen bağımsızlığın oluşumunu sağlamak için çocuk yetiştirmede özerklik eğilimi açıkça vurgulanmaktadır. Araştırmalar bunun, özellikle orta sınıf Anglo-Amerikan toplumunun çoğunluğunda böyle olduğunu gösteriyor. Örneğin, Amerika'daki anne eğitim kurslarında, genç annelere küçük çocuklarını "bırakıvermeleri" söylenir. Bu erken ayrışma önerisi, annelerin çocuklarıyla "birleşme" eğilimine terstir. Hatta annelerden bu (doğal) eğilimlerini frenlemeleri istenmektedir (Kağıtçıbaşı, 2000: 103)

Kişilerde bulunan benliğin başlıca görevleri şu şekilde sıralanabilir (Köknel, 2005: 66-67):

- Kişinin iç güdülerinden yada dürtülerinden gelen denetlemek, engellemek ve düzenlemek,

- Kişinin çevresindeki nesne ve kişilerle bağlantı kurmak, 
- Gerçeğe uyum sağlamak,

- Çevreden gelen uyarımları sınırlamak, sıralamak, zamanlamak,

- Algılamak, saklamak, hatırlamak, düşünmek, karşılaştırmak, çıkarımlar yapmak, yargiya varmak,

- Bildiği kavramları birleştirmek veya bütünleştirmek,

- Kişinin karşılaştığı engelleri aşabilecek güçleri toplamak,

- Geleceğe ilişkin beklenti ve amaçlar saptamak.

Yanılsamalı benlik duyumu, bir taraftan varlığını korumaya ve sürdürmeye çalışan biyolojik bir yapı, bir tarafta ötekilerden ve erken ayrılmışlıktan kaynaklanan bir kişisel benlik duyum ve bir tarafta da hem biyolojik yapının hem de benliğin sonlu ve geçici olduğu bilinci ile var olan bir benliktir. Burada kişisel benlik duyumunun bir yanılsama olduğunu fark ettiren uyarı sonluluk bilincidir. Bu sonluluk bilinci bastırılırsa, açığa çıkmazsa izin verilmezse aslında bir yanılsama olan kişisel benlik sahte bir sonsuzluk içinde yüceltilir ve şişirilir. Dışarıda görkemli, mükemmeliyetçi, ama içi boş bir benliktir. $\mathrm{Bu}$ şişirilmiş içi boş benliğin kültürel ve psikolojik boyutları da mevcuttur. Kısacası boş benlik içine mutlaka bir şeyler alarak içindeki boşluğu doldurmanın peşinde olacaktır. Dolayısıyla bu halde bulduğu an içine aldığı ne ise onunla benliğini inşa edecektir (Özen \& Gülaçtı, 2010).

\section{Benlik Yaklaşımı ve Benlik Sunumu}

Benlik saygısı, psiklojide ve günlük hayatta sıkça kullanılan bir kelimedir. Benlik saygısı kişinin kendine değer vermesi, kendisini ödüllendirmesi, takdir etmesi, onaylaması şeklinde tanımlanabilir. Psikolojide en çok kabul edilen tanım ise "kendimize yönelik beğendiğimiz veya beğenmediğimiz tutumlar" şeklinde yapılan tanımdır. Benlik saygısı, benliğin zihinsel ve davranışsal yönlerine ilaveten değerlendirici ya da etkileyici yönlerinin de yer aldığı geniş bir alanı kapsar. Daha belirgin alanlarda bu yapı ile ilgili olarak benlik değeri, daha geniş bir kavramı açıklarken, kendine güven yada vücut saygısı gibi kavramlar ise benlik saygısının daha dar anlamları için kullanılmaktadır (Uşaklı, 2013: 260).

Benlik yaklaşımı kavramlarının çoğu açık ve net değildir. Ayrıca bu kavramaları deneysel olarak araştırmak zordur. Yine de kişiliğe bakış açısından yararlı bir bakış biçimi oluşturmaktadır. Benliğe ilişkin çeşitli yaklaşımlardan bazıları şunlardır (Cüceloğlu, 2010: 427):

İyimser bir yaklaşım: Benlik kuramlarının en belirgin özelliklerinden biri de iyimser bir bakış açısı oluşturmasıdır. Freud insanı iç dürtülerinin elinde sürekli itilen bir varlık, öğrenme psikologları ise çevresel koşulların tutsağı olarak görür. Buna karşılık benlik kuramcıları, insan doğasının sürekli mutluluğu ve iyiliği aradığını, insanın kendisi ve doğasıyla uyum içinde yaşamak için bilinçli olarak seçimler yaptı̆̆ına inanır. 
Yaşantısından doyum sağlamanın insanın içinde doğuştan var olduğuna inanırlar. Bu görüş, Freud' un sürekli çatışma içinde olan insan görüşünden daha iyimser bir görüştür.

Mekanik Olmayan Bir Yaklaşım: Freud ve diğer öğrenme kuramcılarının insana yaklaşımı mekaniktir. Yani onlara göre mekanik süreç ve güçler bireyin davranışını belirler. Fakat benlik kuramı bireyin, yaşamını doyumluluğa ulaştırma yönünde sürekli seçim yaptığını savunur. Benlik kuramını destekleyen psikologlara göre birey son derece karmaşık bir organizmadır ve kendi kaderi üzerinde kendisinin karar verme gücü vardır. Kişi iyiye gitme, gelişme ve mutluluğa ulaşma yönünde kararlar verir.

"Şimdi ve Burada" Yaklaşımı: Benlik kuramı kişinin başından geçmiş daha önceki olaylara önem vermez ve çocuklukta geçen olayların yetişkin bireylerin davranışlarını etkilediğini düşünmezler. Onların önem verdiği şu anda kişi kendisini ve çevresini nasıl algilamaktadir.

John bir iş görüşmesine gidecektir. Dikkatle hazırlanır, iş konusunda söyleyeceklerinin denemesini yapar. Saçını kestirir, hangi elbiseyi giyeceğini, yelek giymenin fazla resmi olmayacağını düşünür. Belgeleri yanında taşımak için yeni bir çanta almıştır. Randevusuna erken gitmesi gerektiğini bilir. Görüşme yapacağı kişi ile karşılaştığında el sıkması gerektiğini anımsar. Görüşme sırasında dikkatli konuşmaya çalışır ve soruları tam olarak yanıtlamak için çaba harcar. John burada benlik sunumu yapmaktadır. Toplumsal etkileşimin bilinen bir yönü başkalarına verilen izlenimi kontrol ya da yönetme arzusudur. Benlik sunumu başkalarına verilen izlenimi kontrol çabası olarak adlandirılır. Bu sunumun temel amacı istenen sonuca ulaşmak için etkileşimi yapılandırmaktır. John' un buradaki amacı iş teklifi almaktır. John arkadaşlarıyla birlikte olduğunda, bir alışkanlık olarak kendisini eğlenceyi seven, işini çok fazla ciddiye almayan birisi olarak sunabilir. Belirli bir durumda benlik sunumu bir rutin haline geldiğinde, insanlar artık benlik sunum yönetiminin farkında değillerdir. Dikkatlerini durumun başka yönleri üzerinde odaklaştırabilirler (Taylor, Peplau, \& Sears, 2007: 132).

Benlik sunumu, insanların kendileri hakkındaki bazı bilgileri ve imajı diğer insanlara iletme davranışı olarak görülmektedir. Diğer insanlar üzerinde etki yapan her davranışı içermektedir. Benlik sunumu, elbisenin nasıl giyildiğinden, arabanın sürüş şekline, diğer insanlar senin rahat olduğunu bilsin diye korkularını gizlemekten, yürüyüş şekline kadar geniş bir alanı kapsar. Son yıllarda Facebook gibi sosyal medya ortamları benlik sunumu için yeni bir ortam olarak ortaya çıkmıştır. Üniversite öğrencilerinin çoğu, sosyal ağ ortamlarında benlik sunumu yapmaktadırlar (Baumeister \& Bushman, 2014: 106).

Teknolojik araçların kolay bir şekilde elde edildiği ve sıklıkla kullanıldığı günümüz ortamlarda insanlar benlik sunumunu sosyal medya ortamlarında gerçekleştirmektedirler. Özellikle en popüler sosyal medya ağlarından biri olan Facebook aracı online benlik sunumu için ideal bir iletişim aracıdır. İnsanlar zamanlarının çoğunu Facebook platformunda fotoğraf, video, metin gibi birçok araçla iletişimde olduğu kişilere kendi 
durumu ile ilgili mesaj göndermektedir. Bu sebeple bu araştırmada online benlik sunumu için insanların en çok kullandığı sosyal medya aracı olan Facebook seçilmiştir.

\section{Facebook ve Online Benlik Sunumu}

Facebook'da benlik sunumunun yapılmasına ilişkin bir çok özellik bulunmaktadır. Bunlar aşağıdaki şekilde sıralanabilir (Boz, 2012: 45-50): Temel Bilgiler: Benlik sunumuna ilişkin Facebook içerisinde kullanıcının kişisel bilgilerini içeren yaşadığı şehir, memleket, cinsiyet, doğum tarihi, ilgilendikleri, diller, alanlar, bulunduğu coğrafi bölge, kültürel özellikler ve sosyal çıkarımlar gibi birçok özellik mevcuttur. Profil Resmi: Kişinin profil resmi benliği gösteren en önemli resimdir. Kişi bu resmi ile sayfaya girenleri karşılamaktadır. Ayrıca kişi diğer kullanıcılara bir yorum yaptığı taktirde bu resim yine görünerek onu temsil etmektedir. Arkadaş ve aile, ilişki durumları: Facebook' da toplam kişi sayıları ve paylaşımlar, aile ve arkadaşları ile olan durumlarını ortaya koymak için yapılan benlik sunum araçlarıdır. Eğitim ve İş: Facebook profil araçlarından biri de eğitim ve iştir. Bu alan kişinin eğitim durumu ve mesleği hakkında bilgi vermektedir. Diğer benlik sunum alanları: Diğer benlik sunum alanları ise kullanıcılar yorum yapma, resim ve video gibi araçları paylaşarak din, siyasi görüş, sevdiği kişiden sözler kullanarak felsefe yapabilir. Ayrıca, Facebook içerisinde sanat, eğlence, müzik, kitaplar, filmler ve oyun alanları mevcuttur. Bu araçlarda kişinin benlik durumunu tamamlamaya yardımcı olur. Facebook' un temel özelliği (Biçer, 2014) görmek ve görünmektir. Kişiler bir ağ içerisine birçok materyal yükleyerek görünür olmaktadır. Kişinin gönderdiği tüm materyaller hedef kile üzerinde görünür olmak, iyi bir izlenim oluşturmak ve "ben de buradayım" demek amacını taşımaktadır.

Facebook kişiye profil resmi, eğitim durumu, mesleki durum, hobileri, geçmişe ait bilgiler, aile ve iş arkadaşlarına ilişkin bilgiler sunma fırsatı vermektedir. Bu durum da Facebook kişinin gerçek ortamlarda yapabildiği benlik sunum özelliklerini neredeyse tamamını online olarak sanal ortamlarda yapmasına olanak sağlamaktadır. Teknoloji çağında ve herkesin cep telefonu, bilgisayar kullandığı, sosyal medya aracığıla paylaşımların yoğun olduğu günümüzde Facebook online benlik sunumu için etkin bir iletişim aracıdır.

\section{Narsisizm ve Sosyal Medya}

Narsisizm bireylerde normal ve patalojik narsisizm olmak üzere iki şekilde görülmektedir. Normal narsisizm: Bireyin yakın çevresi ile uyumlu olmasını ve çevresinin beklentisini karşılayabilmesidir. Kişinin kendine değer vermesi ve özgüveninin yüksek derecede olmasıdır. Buna karşın patalojik narsisizm bireyin kendinden tamamen emin ve başkalarının düşüncelerini önemsemeyen bir tavırla davranmalarına rağmen içsel süreçte kendine güvenmeyen birey olduklarını göstermesidir. Burada önemli olan nokta bireyin tamamen dıştan gelen yorumlarla beslenmesi ve o yorumlara muhtaç durumda olmasıdır 
(Kara Aziz ve Erdem Atak, 2013). Narsisizm kişinin sahip olmadı̆̆1 temel birtakım niteliklerin karşılanmaması durumunda ortaya çıkan abartılmış benliğin ifadesidir. $\mathrm{Bu}$ sebeple narsistler kendilerini aşırı beğenen, başkalarını küçümseyen, onları kontrol altında tutmaya çalışan, güce ve ilgiye yüksek derecede ihtiyaç duyulan bireyler olarak kendini göstermektedir. Narsisizmde görkemlilik, hassaslık, birincil ve ikincil ayırımlar söz konusudur (Özsoy \& Ardıç, 2017).

Narsistik kişiliğe bakıldığında temelde Yunan mitolojisinden gelen bir hikaye yatmaktadır. Hikayenin kahramanı Narkisos'dur. Narkisos, çok yakışıklı, yürekleri yakan, herkesi kendine aşık eden bir delikanlıdır. Fakat bir çok kızın ve perilerin kalbini kırmıştır. Bir gün periler Tanrı'larına yalvararak Narkisos' un cezalandırılmasını ister:

“Narkisos” da düşşsün aşka

Ve acı çeksin, aynı bize çektirdiği gibi

O da, bizim gibi aşık olsun

Ve görsün umutsuzluğu"

Yakarışları duyan Tanrılar “Başkalarını sevmeyen kendini sevsin!" dediler. Cezalandırma verme süresi uzun sürmedi. Avdan dönen Narkisos susayıp duru bir pınara eğilince suda kendi yüzünü gördü. Yansımanın kendine ait olduğunu fark etti ve "Başkaları benim yüzümden ne acılar çekmiş; şimdi anlıyorum" dedi. "Kendime olan sevgimle yanıyorum ben. Suda yansıyan bu güzelliğe nasıl kavuşabilir? O güzellikten vazgeçemem de. Artık yalnız ölüm kurtarır beni” der ve devam eder.

“... Anlıyorum o benim, aldatmiyor beni artık hayalim

Tutuşturan da ben, tutuşan da, kendime olan sevgimle yanıyorum.

..... Sevdiğim uzak olsa keşke..."

Böylece, Narkisos su kıyısında kendine bakarak eriyip gider. Can çıkar huy çıkmaz derler. Narkisos Ölüler Ülkesi'nde Stiks sularına bakıp kendini seyretmeye devam eder (Hughes, 1997; Aktaran:K1ziltan, 2012).

Narsistik kişilik temeli bir mit olarak geçmişten günümüze anlatılmaktadır. Yakışıklı kişinin kızları ve perileri kızdırması ile başlamakta ve kendisine olan sevgisi, kendisini aşırı beğenmesi, kendisini yücelten ifadeler bulunması ile sonlanmaktadır. Narsistik kişiliğe bakıldığında yukarıdaki hikâyeden de anlaşılacağı üzere kişinin kendisini fiziksel ve psikolojik açından abartılı olarak beğenmesi özelliğidir. Yaşamakta olduğumuz teknoloji çağında insanlar sosyal medya ortamlarında kendileri ile ilgili fiziksel, psikolojik ve çeşitli davranışları ile ilgili abartılı sunumlar yaptığı bilinmektedir. Çalışmanın bakış açısı tam da bu yöndedir.

Konu ile ilgili çalışmalara bakıldığında online benlik sunumu ve narsisizm ile ilgili Türkiye'de ve Dünya'da bir çok çalışma yapılmıştır. Bu çalışmalardan bazı örnekler 
araştırmamıza dahil edilmiştir. Ayrıca narsisiz ile ilgili çalışmaların bir kısmı online benlik sunumu yerine online sosyal medya bağımlılı̆̆ı altında da yapılmıştır. Online sosyal medya bağımlılığında bireyler online benlik sunumunda olduğu sosyal medya ortamlarında benzer özellikler kullandığı çalışmalardan da anlaşılmaktadır.

Sosyal ağ siteleri bağımlılığı karmaşıktır ve biyolojik, psikolojik, sosyal ve kültürel faktörlere bağlıdır. Şu ana kadar duygusal, ilişkisel, sağlık ve performans problemleri ile ilgili birçok çalışma yapılmıştır. Neredeyse her alan bu konu ile ilgili bağlantılı olmaktadır (Andreassen, 2015). Alemdar ve arkadaşları (2017) tarafından yapılan çalışmaya göre üniversite öğrencilerinin sosyal medyada özçekimlerini paylaşımları ve bu davranışın narsisizm ile ilişkisi olduğunu tespit etmişlerdir. Örneğin kendini seven ve beğenen katılımcıların beğenilme arzusu taşıdıkları aracı olarak da özçekimlerini sosyal medya uygulamalarında paylaştıklarını tespit etmişlerdir. (Yeniçeri Alemdar ve ark., 2017). Ayrıca özçekim paylaşımında katılımcıların, diğerlerinin yorumlarını önemsedikleri ve pozitif geri bildirim ile övülme amacı taşıdıkları sonucuna ulaşmışlar. Olumlu yorumlar ve beğeni sayısındaki artış bu noktada ödül davranışı ile ilişkilendirilebilir.

İletişim fakültesi öğrencilerinin narsistik yanıtları ile sosyal ă̆ aktiviteleri arasında zayıf ancak pozitif yönlü, anlamlı bir ilişki bulunmuştur. Sosyal ağları ne ölçüde kendini sunma amacıyla kullandıklarını ortaya koymak ve narsisizm belirtileri ve sosyal ağların kullanım nedenleri olarak kendini ifşa, duygusal ifşa, ilgi çekmek ve gerçek ve gizli kişilik özellikleri birlikteliğine göre şu sonuçlara ulaşılmıştır (Ertürk \& Eray, 2016): Kendini ifşa: Platformlarda durumu güncelleme, profili güncellemek, sanatsal ve güncel etkinlikler paylaşmak, özel etkinlik fotosu oluşturmak, gündelik olaylara dair fotoğraf paylaşma açısından narsistik dışa vurumu yüksek puanda çıkan katılımcıların, kendini ifşa etme amaçlı sosyal medyayı kullanmışlardır. Duygusal ifşa: Narsistik dışa vurumu yüksek puanda çıkan katılımcılar, yaşantılarından kesitler paylaşmak için sosyal medyayı kullandıkları tespit edilmiştir. İlgi çekme: Narsistik dışa vurumu yüksek puanda çıkan katılımcıların, dikkat ve ilgi çekmek için sosyal medyayı kullandıkları tespit edilmiştir.

Önemi her geçen gün artan Facebook, insanların günlük yaşantılarının önemli bir parçasını oluşturmaktadır. Bu uygulama insanların olumlu ve olumsuz davranışları hakkında sinyaller vermektedir. Narsisizm ile Facebook' da "vitrin" (durum güncelleme sıklığı, fotoğraf yükleme, profil bilgilerinin güncelleme sıklıkları) arasında pozitif yönde ve güçlü bir ilişki olduğu tespit edilmiştir (Oğuz, 2016).

Bir sosyal paylaşım ağı olan sosyal medya kanalları son yıllarda insan hayatında önemli bir yer edinmiştir. Web 2.0 teknolojisi aracılığıyla etkileşimin ve paylaşımın arttı̆̆ sanal dünya yüz yüze iletişimin gerekliliğini ortadan kaldırmaktadır. Bunun yerine sosyal medya aracılığıyla iletişim popüler olmuştur. Bu yeni medya kişinin kendisini istediği gibi tanımlayacağı yeni bir kimlik inşa edebileceği bir ortam ve izlenebileceği bir podyum olmuştur. Bu sebeple sürekli kullanıcı sayısını artıran sosyal medya sitelerinin etkilerinin tartışılması son derece önemlidir. Sosyal medya bireyi pek çok anlamda etkilemekle birlikte narsisizm kültürünün yayılmasında da en önemli etkendir. Sosyal paylaşım sitesi 
olan Instagram bir taraftan narsistik semptomların anlaşılması diğer taraftan görsel kültürün gözmerkezci (occularcentric) anlam inşa etme yönünü göstermesi açısından önem taşımaktadır. Gözmerkezci toplumun oto-erotizm, beden teşhirciliği, erotik nesne kullanımı, tanrısallığa öykünme, gücün psikotik çağrışımları beraberinde güç, şöhret, para, beden ve cinsellik gibi kendi fetişistik değerlerini de yaratmaktadır. Görmenin aşırılı̆̆ını sunan yeni medya böylece egosantrik bireyin koordinatlarını da vermektedir (Alanka ve Cezik, 2016).

Şekil 1: Kim Kardashian'ın Instagram Fotoğraflarının Analizi Şeması

\begin{tabular}{|c|c|c|}
\hline Gösteren Düz Anlam & Gösterilen Yan Anlam & $\begin{array}{l}\text { Narsistik } \\
\text { Anlam }\end{array}$ \\
\hline Avatar & Sanal ben & $\begin{array}{l}\text { Narsistik ben'in } \\
\text { virtüelleşmesi }\end{array}$ \\
\hline Emoji & Duygusal ifadeler & Ben'in sanal ifadeleri \\
\hline Figürasyonlar & Egonun dışavurumu & Kendiliğin sublimasyonu \\
\hline Beden teşhiri & Cinsellik & $\begin{array}{l}\text { Oto-erotizmin sanal- } \\
\text { gerçekliği }\end{array}$ \\
\hline Beden dili ifadeleri & Erotizm & Narsistik beden fetişizmi \\
\hline
\end{tabular}

Kaynak: (Alanka \& Cezik, 2016).

Şekil 1'de görüldüğü üzere analiz edilen fotoğrafta Kim Kardashian' in duygusal görüntüleri (emoji) yer alırken bedenin sanal alana aktarımı ile ego nesnellik ötesi (transandantal) bir düzleme taşınmaktadır. Fotoğraftaki yüz ve beden ifadeleri, sakız, kep, şeytan boynuzu, melek halesi, saç ve beden şekilleri, kişinin egosunun sanal gerçeklikten yeniden inşa edilmelerine birer gönderme yapmaktadır. Bedenin avatarlaşıp erotizm ve cinsellik çağrışımlarıyla örülmesi göstergeler düzleminde oto-erotizmi ve narsistik halini yansıtmaktadır. Aynı şekilde kendine (self) ve kendi bedenine (flesh) gönderme yapan nesneler ve ifadeler ile kendinin yüceltilmesine (sublimasyon) sebep olmakta ve bu durum da narsistik kişilik bozukluğunun göstergesi olarak açılanabilir (Alanka ve Cezik, 2016). 
Lee ve Sung'un yaptığı çalışmaya göre Narsisizm ile özçekim (selfie) davranışları arasındaki ilişkiyi ölçmek için 315 Koreli insan üzerinde araştırma yapmışlardır. Yapılan araştırma sonucunda narsisizm seviyesi yüksek olan kişiler sanal ortamda diğer insanların yorum ve beğenme (comment ve like) davranışlarında daha dikkatli oldukları, diğer insanların özçekim ve beğenmelerine daha fazla baktıkları, ayrıca gelecekte daha fazla özçekim gönderme eğiliminde olduklarını tespit etmişlerdir (2016).

Sosyal medya kullanım bağımlılığı ile narsisizm arasındaki ilişkiyi ölçmek için \% 65'i kadın (15,372 kişi) ve \% 35 'i erkek (8234 kişi) olmak üzere toplam 23,532 kişi üzerinde geniş bir kitlede araştırma yapılmıştır. Yapılan araştırmaya göre, sosyal medya kullanım bağımlılığı ile narsisiz arasında pozitif yönde ilişki bulunmuştur $(r=0,06)$ ve yine aynı araştırmada sosyal medya kullanım bağımlılı̆̆ı ile benlik saygısı arasında negatif yönde bir ilişki olduğu $(r=-0,25)$ tespit edilmiştir. Ayrıca gençler, kadınlar, bir ilişkisi olmayanlar, öğrenciler ve az eğitimli olanlar sosyal medya bağımlılık ölçeğinde yüksek puan almışlardır (Andreassen ve ark. 2017).

\section{Yöntem}

Araştırmada kullanılan yöntem üniversitede eğitim gören öğrencilerin narsisizm ve Facebook'da benlik sunumu arasındaki ilişkiyi ortaya koymayı amaçlayan bir survey araştırma yöntemidir. Bu bağlamda çalışmada, önceden geçerlilik ve güvenirlik saptanmış ölçekleri içeren bir bilgi envanteri kullanılarak anket türü soru sorma tekniğinden faydalanılmıştır. Araştırma ile ilgili veriler bilgi toplama envanteri ile Aksaray Üniversitesi'nde Sosyal Bilimler Meslek Yüksekokulu ile İktisadi ve Bilimler Fakültesi'ndeki bazı bölümlerde öğrenim gören öğrencilerden 2016-2017 Güz döneminde elde edilmiştir.

$\mathrm{Bu}$ araştırmada iki adet ölçek kullanılmıştır. Bunlardan bir tanesi Narsistik Kişilik Envanteri'dir (Narcissistic Personality Inventory-NPI). Narsistik Kişilik Envanteri (NKE) Atay (2009) tarafından Türkçe' ye uyarlanmışır. Elde edilen bulgulara göre bu ölçek yeterli güvenirlik ve geçerlilik değerlerine sahiptir. Envanter 16 sorudan oluşmakta olup iki seçenek vardır ve her seçenekten yalnız bir tanesi cevaplanmıştır.

Bir diğer ölçek ise Değiştirilmiş Benlik Sunumu Taktikleri Ölçeği'dir. Davranış ifadelerinden oluşan taktik ölçeğinde 5'li likert tipi ölçek kullanılmıştır. Ölçek içerisinde örnek davranış sergileme, kendini sevdirme, tehdit etme, kendini acındırma ve niteliklerini tanıtma alt boyutları vardır (Boz, 2012: 59). Ölçek Leea ve arkadaşları tarafından geliştirilmiştir (1999).

$\mathrm{Bu}$ çalışmada sosyal medyada benlik sunum aracı olan Facebook'un narsisizm ile doğrudan bir ilişkisi olup olmadığını ortaya koymayı amaçlanmaktadır. Bu amaç doğrultusunda aşağıdaki sorulara cevap aranmıştır:

1. Narsisizm ve online benlik sunumu arasında bir ilişki var mıdır?

2. Narsisizm ve online benlik sunumu alt boyutları arasında bir ilişki var mıdır? 
3. Cinsiyet değişkeni ile online benlik sunu arasında anlamlı bir farklılık var mıdır?

4. Online benlik sunumu kullanıcılarının günlük internet ve Facebook kullanım durumları nelerdir?

\section{Bulgular}

Araştırmaya toplam 181 kişi katılmıştır. Katılanların yaş dağılımları incelendiğinde, \% 55,8' inin 15-20 yaş aralığında, \% 39,8' inin 21-25 yaş aralığında \% 1,7' sinin 26-30 yaş aralığında ve \% 2,8' inin 36 ve üstünde olduğu tespit edilmiştir. Cinsiyet dağılımı incelendiğinde ise katılımcıların \% 51,4 'ünün (93 kişi) kadın ve \% 48,6' sının (88 kişi) erkek olduğu görülmektedir. Katılımcıların \% 23,8' inin Yönetim Bilişim Sistemleri lisans, \% 19,3 'ünün Muhasebe ve Finansman, \% 18,8' inin Halkla İlişkiler ve Tanıtım, \% 18,2'sinin Büro Yönetimi ve Yönetici Asistanlığı̆, \% 17,1' inin İş Sağlığ1 ve Güvenliği ön lisan ve \% 2,8'inin Gazetecilik lisans programlarında öğrenim görmektedirler.

\section{Katılımcıların Günlük İnternet Kullanımı, Facebook Kullanımı, Facebook' da Arkadaş Sayısı, Anne Eğitimi Durumu ve Baba Eğitim Durumu}

Aşağıdaki Tablo 1 görüldüğü üzere günlük internet kullanma süreleri verilmiştir. Buna göre araştırmaya katılan öğrencilerin \% 58' inin (105 kişi) 4 saat ve üzeri internet kullanmaktadırlar. Öğrencilerin yalnız \% 4,4 ü (8 kişi) 1 saat internet kullanmaktadır ve bu durum da düşük bir orandır. Öğrencilerin çoğunun 2 saat ve üzeri internet kullandı̆̆ görülmektedir.

Tablo 1: Günlük internet Kullanma Süresi

\begin{tabular}{lrrr}
\hline \multicolumn{1}{c}{ Kullanma Süresi } & Frekans & Yüzde & Toplam Yüzde \\
\hline $1 \mathrm{dk}$. - 59 dk. arası & 8 & 4,4 & 4,4 \\
\hline $\begin{array}{l}1 \text { saat - 1 saat 59 dk. } \\
\text { arasi }\end{array}$ & 21 & 11,6 & 16,0 \\
\hline $\begin{array}{l}\text { 2 saat - 2 saat 29 dk. } \\
\text { arası }\end{array}$ & 23 & 12,7 & 28,7 \\
\hline $\begin{array}{l}\text { 3 saat - 3 saat 59 dk. } \\
\text { arasi }\end{array}$ & 24 & 13,3 & 42,0 \\
\hline 4 saat ve üzeri & 105 & 58,0 & 100,0 \\
\hline \begin{tabular}{l} 
Toplam \\
\hline
\end{tabular} & 181 & 100,0 & \\
\hline
\end{tabular}


Tablo 2'ye bakıldığında öğrencilerin \% 70,2'sinin (127 kişi) yaklaşık bir saat Facebook kullandıkları tespit edilmiştir. Bu durum da öğrencilerin çoğunun Facebook hesaplarına girdiği ve kısa sürede bu internet sayfasından çıktı̆̆ı bilgisine ulaşılabilir. Öğrencilerin \% 15,5' inin (28 kişi) iki saat ve daha fazla Facebook kullandıkları tespit edilmiştir.

Tablo 2: Günlük Facebook Kullanma Süresi

\begin{tabular}{lrrr}
\hline \multicolumn{1}{c}{ Kullanma Süresi } & Frekans & Yüzde & Toplam Yüzde \\
\hline 1 dk. -59 dk. arası & 127 & 70,2 & 70,2 \\
\hline 1 saat - 1 saat 59 dk. arası & 26 & 14,4 & 84,5 \\
\hline 2 saat - 2 saat 29 dk. arası & 7 & 3,9 & 88,4 \\
\hline 3 saat - 3 saat 59 dk. arası & 7 & 3,9 & 92,3 \\
\hline 4 saat ve üzeri & 14 & 7,7 & 100,0 \\
\hline Toplam & 181 & 100,0 & \\
\hline
\end{tabular}

Katılımcıların annelerinin eğitim durumu yapılan analiz sonucunda okur-yazar olmayanlar \% 11,6 (21 kişi), ilköğretim mezunu \% 73 (133 kişi), lise \% 11,6 (21 kişi), üniversite \% 2,8 (5 kişi) ve lisans üstü 0,6 (1 kişi) tespit edilmiştir. Katılımcıların babalarının eğitim durumuna bakıldığında okur-yazar olmayanlar \% 1,7 (3 kişi), ilköğretim mezunu \% 61,9 (112 kişi), lise \% 26 (47 kişi), üniversite \% 9,4 (17 kişi) ve lisans üstü mezunu 1,1 (2 kişi) olduğu tespit edilmiştir.

Facebook kullanıcılarının arkadaş sayısı ise kullanıcıların \% 25 (38 kişi) 1- 249 arası, \% 37' si (55 kişi) 25-499 arası, \% 14' ü (21 kişi) 500- 749 arası, \% 7 si ( 11 kişi) 750 - 999 arası, \% 6,7 si 10 kişi, \% 2' si (3 kişi) 1250- 1499 arası, \% 8'i (12 kişi) ise 1500- 22000 arası olduğu tespit edilmiştir. Kullanıcıların \% 20 si (31 kişi) ise arkadaş sayılarını belirtmemişlerdir.

Tablo 3: Narsisizm ve Online Benlik Sunumu (Facebook) Arasındaki İlişki

\begin{tabular}{|c|c|c|c|c|c|c|c|c|}
\hline $\begin{array}{l}\text { Genel ve } \\
\text { Alt } \\
\text { Boyutları }\end{array}$ & & 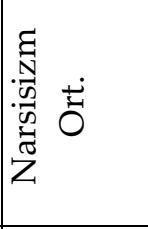 & 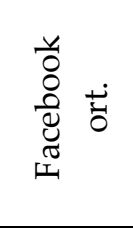 & 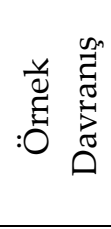 & 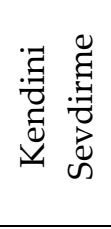 & 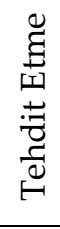 & 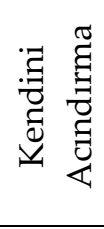 & 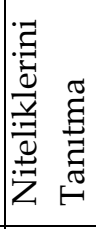 \\
\hline \multirow[t]{2}{*}{$\begin{array}{l}\text { Narsisizm } \\
\text { Ort. }\end{array}$} & $\begin{array}{l}\text { Pearson } \\
\text { Correlation }\end{array}$ & & & & & & & \\
\hline & Sig. (1-tailed) & & & & & & & \\
\hline \multirow[t]{2}{*}{$\begin{array}{l}\text { Facebook } \\
\text { Ort. }\end{array}$} & $\begin{array}{l}\text { Pearson } \\
\text { Correlation }\end{array}$ &, $174\left(^{*}\right)$ & & & & & & \\
\hline & Sig. (1-tailed) & 021 & & & & & & \\
\hline Örnek & Pearson & 124 & $\left.489^{(* *}\right)$ & & & & & \\
\hline
\end{tabular}




\begin{tabular}{|c|c|c|c|c|c|c|c|}
\hline \multirow{2}{*}{ Davranış } & Correlation & & & & & & \\
\hline & Sig. (1-tailed) & ,074 &, 000 & & & & \\
\hline \multirow[t]{2}{*}{$\begin{array}{l}\text { Kendini } \\
\text { Sevdirme }\end{array}$} & $\begin{array}{l}\text { Pearson } \\
\text { Correlation }\end{array}$ & 124 &, $927(* *)$ &, $376\left(^{* *}\right)$ & & & \\
\hline & Sig. (1-tailed) & ,074 &, 000 & ,000 & & & \\
\hline \multirow[t]{2}{*}{ Tehdit Etme } & $\begin{array}{l}\text { Pearson } \\
\text { Correlation }\end{array}$ & 134 &, $833\left({ }^{* *}\right)$ & ,125 &, $768\left(^{* *}\right)$ & & \\
\hline & Sig. (1-tailed) & 059 & 000 & 072 & ,000 & & \\
\hline \multirow[t]{2}{*}{$\begin{array}{l}\text { Kendini } \\
\text { Acındırma }\end{array}$} & $\begin{array}{l}\text { Pearson } \\
\text { Correlation }\end{array}$ &, $191\left(^{*}\right)$ &, $897(* *)$ &, $291\left(^{* *}\right)$ &, $768\left(^{* *}\right)$ &, $\left.788^{(* *}\right)$ & \\
\hline & Sig. (1-tailed) & ,013 & ,000 & , 000 & ,000 & 000 & \\
\hline \multirow[t]{2}{*}{$\begin{array}{l}\text { Niteliklerini } \\
\text { Tanitma }\end{array}$} & $\begin{array}{l}\text { Pearson } \\
\text { Correlation }\end{array}$ &, $154\left(^{*}\right)$ &, $900(* *)$ &, $\left.378^{(* *}\right)$ &, $791(* *)$ &, $\left.6566^{* *}\right)$ &, $780(* *)$ \\
\hline & Sig. (1-tailed) & ,036 & ,000 & ,000 & ,000 & ,000 & ,000 \\
\hline
\end{tabular}

Yukarıdaki tabloda görüldüğü gibi narsisizmin online benlik sunumu ile ilişkisi, doğru yönde pozitif bir ilişkisi olduğu tespit edilmiştir. Bununla birlikte alt boyutlara bakıldığında narsisizmin online benlik sunumunda kendini acındırma ve niteliklerini tanıtma arasında yine doğru yönde pozitif bir ilişkisi olduğu görünmektedir. Ayrıca online benlik sunumunun kendi içerisinde örnek davranış, tehdit etme, kendini acındırma ve niteliklerini tanıtma arasında güçlü bir şekilde doğru yönde pozitif bir ilişkisi olduğu tespit edilmiştir.

\section{Araştırmada Cinsiyet ile Online Benlik Sunumu Arasındaki t Testi ve Günlük Facebook Kullanımı ile Online Benlik Sunumu ANOVA Testi}

Cinsiyete Facebook üzerinden katılımcıların benlik sunumlarına bakıldığında bu iki değişken arasında anlamlı bir farklılık ortaya çıktığı gözlenmektedir $(\mathrm{t}=-2,05, \mathrm{sd}=1.01$, $\mathrm{p}=.042)$. Bu farklılığın nedeni incelendiğinde erkeklerin $(\mathrm{AO}=2,62)$ kadınlara $(\mathrm{AO}=2.31)$ göre Facebook'u benlik sunum aracı olarak daha fazla kabul ettikleri ve kullandıkları sonucuna ulaşılmaktadır. Katılımcıların günlük Facebook kullanımı ile online benlik sunumları arasında istatistiki açıdan anlamlı bir farklılık tespit edilememiştir $(\mathrm{F}=.439, \mathrm{df}=4$, $\mathrm{p}=.780)$.

\section{Sonuç}

Kişinin kendini çevresine ifade etme derecesi (izlenim bırakma kabiliyeti) çok farklı iki tür işaretleşme faaliyetini içerir: Biri verdiği izlenim, diğeri yaydığı izlenim. İlki sözlü simgeleri veya onların yerine geçen şeyleri içerir; kişi bunları yalnızca, kendisinin ve başkalarının bu simgelere yükledikleri anlamları iletmek için kullanır. İkincisi ise, gözlemcilerin kişi hakkında bulgu sağlayabileceği beklentisiyle değerlendirilen çok çeşitli 
eylemleri içerir (Goffman, 2016: 16). Kişinin çevresine verdiği ve yaydığı izlenim benlik sunumudur. Kişi benlik sunumunu hayatının her safhasında gerçekleştirmektedir.

İnsanlar benlik sunumlarını çağımızın önemli araçları olan sosyal medya ortamlarında da gerçekleştirmektedir. Fotoğrafların paylaşımı, profillerin güncellenmesi, özcekimler, anlık sanal hikayeler gibi bir çok benlik sunum araçları bulunmaktadır. Hatta sosyal medya kullanıcıları çevresinden gelen beğenilme ve beğenilmeme durumlarına göre kendi davranışlarını değiştirme yoluna gitmektedir.

Narsistik kişilik ise kişinin kendini abartılı bir biçimde beğenmesi durumudur. Online ortamlardaki etkileşim insan kişiliklerini de etkilemektedir. $\mathrm{Bu}$ araştırmada Facebook'da online benlik sunumu ile narsisizm araştırılmıştır. Yapılan araştırmada online benlik sunumu ile narsisizm arasında bir ilişki olduğu tespit edilmiştir. Sonuç olarak sosyal medyanın narsisizm kişiliğe sahip insanların çoğalmasında etkili olduğu ve toplumu değiştirdiği söylenebilir.

\section{Kaynakça}

Alanka, Ö., \& Cezik, A. (2016). Dijital Kibir: Sosyal Medyadaki Narsistik Ritüellere İlişkin Bir İnceleme. TRT AKADEMI, 548-569.

Andreassen, C. S. (2015). Online Social Network Site Additction: A Comprehensive Review. Current Addiction Reports, 175-184.

Andreassen, C., Pallesen, S., \& Griffiths, M. (2017). The Relationship Between Addictive Use Of Social Media, Narcissism, and Self-Esteem: Finding From a Large National Survey. Addictive Behaviors, 287-293.

Atay, S. (2009). Narsistik Kişilik Envanteri'nin Türkçe'ye Standardizasyonu. Gazi Üniversitesi İktisadi ve İdari Bilimler Fakültesi Dergisi, 181-196.

Baumeister, R. F., \& Bushman, B. J. (2014). Social Psychology and Human Nature. Canada: Wadsworth Cengage Learning.

Biçer, S. (2014). Goffman Metodolojisinden Hareketle Facebook Üzerinde Akademisyenlerin Kendini Sunma Davranışı. Adıyaman Üniversitesi Sosyal Bilimler Enstitüsü Dergisi, 66-100.

Boz, N. (2012). Yeni İletişim Ortamlarında Dijital Kimlik ve Benlik Sunumu. İstanbul: Marmara Üniversitesi Sosyal Bilimler Enstitüsü-Yayınlanmamış Toktora Tezi.

Boz, N. (2012). Yeni İletişim Ortamlarında Dijital Kimlik ve Benlik Sunumu. İstanbul: Marmara Üniversitesi Sosyal Bilimler Enstitüsü, Yayınlanmamış Doktora Tezi.

Ceylan, M., Evrensel, A., Ünsalver, B., \& Cömert, G. (2015). Benlik Gelişiminin Nöropsikolojik Temelleri. Psikiyatride Güncel Yalaşımlar-Current Approaches in Psychiatry, 255-264.

Ertürk, Y. D., \& Eray, T. E. (2016). Fenomenolojik Bir Kavram Olarak Kendilik ve Sosyal Ağlarda Kendilik Sunumu ile Narsistik Eğilimler İlişkisi: İletişim Fakültesi (İ.Ü.İ.F.) Öğrencileri Üzerine Bir Ön Çalışma. Intermedia International e-Journal, 12-29.

Goffman, E., (2016) Günlük Yaşamda Benlik Sunumu, Çev. Barış Cezar, İstanbul: Metis Yayınları

Güney, S. (2016). Davranış Bilimleri. Ankara: Nobel Akademik Yayıncılık.

Hayes, N. (2011). Psikolojiyi Anlamak. İstanbul: Optimist Yayın ve Dağıtım. 
Hughes, T. (2018, 01 03). An Introduction to Tales from Ovid. Discovering Literature: 20th Century: https://www.bl.uk/20th-century-literature/articles/an-introduction-to-tales-from-ovid adresinden alınd 1

Kağıtçıbaış, Ç. (2000). Kültürel Psikoloji, Kültür Bağlamında İnsan ve Aile. İstanbul: Evrim Yayinevi.

Kağıtçıbaşı, Ç. (2010). Benlik, Aile ve İnsan Gelişimi. İstanbul: Koç Üniversitesi Yayınları.

Kara Aziz, M., \& Erdem Atak, İ. (2013). Narsisizm ve Narsisizmle İlgili Araştırmalar Üzerine Bir Gözden Geçirme. Nesne Dergisi, 44-59.

Kızıltan, H. (2012). Hayalperest. PSIKKEART , 6-11.

Köknel, Ö. (2005). Kaygıdan Mutluluğa. İstanbul: Altın Kitaplar.

Lee, J.-A., \& Sung, Y. (2016). Hide-and-Seek: Narcissism and "Selfie"- Related Behavior. Cyberpsychology, Behavior, and Social Networking, 347-352.

Mutlu, E. (2012). İletişim Sözlüğü. Ankara: Sofos.

Oğuz, T. (2016). Çağdaş Nakisisos'lar: Facebook Kullanım Alışkanlıkları ve Narsisizm. Selçuk İletişim, 51-68.

Özen, Y., \& Gülaçtı, F. (2010). Benlik-Kavramıve Benliğin Gelişimi Bilen Benliğe Gereksimin Var Mı? Erzincan Eğitim Fakültesi Dergisi, 21-38.

Özlem, D. (2010). Kültür Bilimileri ve Kültür Felsefesi: Felsefe. İstanbul : Notos Kitap, .

Özsoy, E., \& Ardıç, K. (2017). Karanlık Üçlü'nün (Narsisizm, Makyavelizm ve Psikopati) İş Tatminine Etkisinin İncelenmesi. Yönetim ve Ekonomi, 391-406.

Smith, P., \& Riley, A. (2016). Kültürel Kurama Giriş. Ankara: Dipnot Yayınları.

Taylor, S., Peplau, L. A., \& Sears, D. (2007). Sosyal Psikoloji (Social Psychology). (A. Dönmez, Çev.) Ankara: İmge Kitabevi.

Uşaklı, H. (2013). Kişilik ve Benlik. A. Şimşek, \& Ö. Eroğlu içinde, Davranış Bilimleri (s. 240-272). Konya: Eğitim Yayınevi.

Yeniçeri Alemdar, M., İşbilen, D., Demirel, K., \& Günal Telli, N. (2017). Özçekim Davranışı Narsisizm Göstergesi Olabilir Mi? Özçekim ve Narsisizm Arasındaki İlişkiyi Tanımlamaya Yönelik Bir Nitel Araştırma. Global Media Journal TR Edition, 71-97. 